\title{
Between Tradition and Sustainable Innovation: Empirical Evidence for the Role of Geographical Indications
}

\author{
Alessandro Gocci ${ }^{1,2}$, Christoph Luetge ${ }^{2}$, Hristos Vakoufaris ${ }^{3}$ \\ ${ }^{1}$ Max Planck Institute for Innovation and Competition, Munich, Germany \\ 2 TUM School of Management, Technical University of Munich, Munich, Germany \\ ${ }^{3}$ Ministry of Rural development and Food, Variety Research Department of Cultivated Plants, Sindos, Greece \\ Correspondence: Alessandro Gocci, Max Planck Institute for Innovation and Competition, Munich, Germany.
}

Received: July 27, 2020

doi:10.5539/ibr.v13n9p101
Accepted: August 18, $2020 \quad$ Online Published: August 20, 2020

URL: https://doi.org/10.5539/ibr.v13n9p101

\begin{abstract}
The role of innovation without disrupting tradition is gaining importance within GI research. Next to maintaining competitiveness within niche markets, the topic of sustainability is put into focus by different GI stakeholders. This paper aims to shed light on the combination of tradition and innovation and their effects on long-term sustainability. A new framework was developed combining the concept of a GI entrepreneur, the TISyn model, and the Triple-Bottom line. It can be used for holistic research of GI agricultural productions while focusing not only on economic factors but also on social and environmental ones. Three protected designations of origin (PDO) products were researched as case studies using the framework: Stromberger Pflaume (Germany), Carciofo Spinoso di Sardegna (Italy), and Vlaams Brabantse tafeldruif (Belgium). The selection of these cases was based on a qualitative content analysis of GI documents, with the possibility of comparing different national and institutional contexts, while using products belonging to the same product class (fruits and vegetables). Furthermore, the selection was refined by the available empirical material and the willingness and ability of GI stakeholders to engage in topics investigated here. The comparative case study approach allows us to qualitatively assess differences between the dimensions of sustainability within different contexts. Thus, it will help build a new theory around the synergy of tradition and innovation within the GI scheme. The results can support new GI policy designs and their implementation, which may benefit all the GI stakeholders in the long-run.
\end{abstract}

Keywords: geographical indications, tradition, innovation, synergy, diversification, sustainability, case study

\section{Introduction}

"The introduction and diffusion of innovations in agriculture has been one of the fundamental drivers of economic and social change on a world scale" (Nuvolari \& Tartari, 2014).

Innovations play a key role in maintaining the competitiveness of a good or service. Therefore, we argue that a discourse of how innovation interacts with geographical indication (GI) products is required, to remove uncertainties about its effects on traditional practices which characterize GIs. The GI scheme, as intellectual property, communicates features such as quality and reputation to the consumer through two different types of labels for agri and non-agri products: protected designation of origin (PDO) and protected geographical indication (PGI) (European Commission, 2012; Quiñones-Ruiz et al., 2016). Their classification is made according to the geographical origin and the strength of the product link with the area. All standard procedures for producing a GI through traditional practices are codified within a national specific document called product specification (PS) (Edelmann et al., 2020). There is a common understanding that GIs can be perceived as 'evolving social-ecological systems' which benefit from constant learning cycles (Quiñones-Ruiz, Penker, Vogl \& Samper-Gartner, 2015; Edelmann et al., 2020). GI producers usually operate in collectives, however, we regard them as individual entrepreneurs responsible for their agri-business which is influenced by the shared traditional heritage. On the one hand, GIs are gatekeepers of traditional practices in the agri-food realm, and on the other hand, enablers of innovations. Therefore, we argue that both notions are required to analyze GI case studies since GIs, as social-ecological systems, are multi-dimensional. According to Mancini (2013), GIs would perish if they only focus on tradition, without engaging in innovation. 
In this article, we look at the synergy between tradition and innovation in agriculture and the impact on sustainability. Specifically, we investigate how GI producers strive to follow a differentiated approach based on tradition and innovation by expanding the agricultural functions of GI production. They are not limited to the economic gains but include social and environmental ones. Since the terms innovation and tradition are complex, some working definitions are provided below.

A classification of innovations in agriculture is provided by Nuvolari and Tartari (2014):

i. "biological innovations $[\ldots]$,

ii. improvements or transformations of practices of cultivation, $[\ldots]$

iii. mechanization, $[\ldots]$

iv. chemical products [...]" (Nuvolari \& Tartari, 2014).

This conceptualization suits a practical analysis of cases while following the most common definition provided by Lundvall (2010): "[Innovation is] an ongoing process of leaving, searching, and exploring which results in: (1) new products; (2) new techniques; (3) new forms of organization and (4) new markets" (Lundvall, 2010). We argue that both classifications are required to analyze GI case studies since GIs, as social-ecological systems, are multi-dimensional. Marescotti et al. (2020) examined the amendments of PS to find evidence of changes related to the environment. They give the example of Cerezas de la Montaña de Alicante PGI, which introduced new varieties in order to cope with climate change (Marescotti et al., 2020). This innovation can be classified in category one from Lundvall (2010), "new products" as well as Nuvolari and Tartari (2014) classification of "biological innovations".

There are many definitions of tradition; one commonly used in GI research is the term 'terroir' combining natural and human factors, which characterize the geographical area (Riviezzo, Garofano, Granata \& Kakavand, 2017). Traditions are customs or beliefs taught by one generation to the next, and they play an essential role in cultural identification (Weichselbaum, Benelam \& Soares Costa, 2009). According to Hobsbawm and Ranger (2012) the object and characteristic of traditions is invariance. Attempts to define traditional agri-food products are characterized by a paradoxical duality: on the one hand they must remain fixed in time, and on the other hand they can change their characteristics. In this article we focus on the two concepts 'traditional knowledge' and 'local knowledge' because they highlight all important factors of tradition perceived within GIs, and they are relevant for the notion of traditional agri-food products. Reyes-Garcia et al. (2014) define traditional knowledge as the heritage of non-industrial communities characterized by a continuous historical and intergenerational cycle found in rural areas. Local knowledge is defined by Beckford and Barker (2007) as: "Dynamic and complex bodies of know-how, practices, and skills that are developed and sustained by peoples/communities with shared histories and experiences" (Beckford \& Barker, 2007). Both definitions highlight the complexity of traditional aspects while providing a suitable approach for the analysis of traditional factors within GIs. We believe that through innovations embedded in traditional/local knowledge, GI products become more resilient.

There is empirical data from GI researchers about the impact of innovation on tradition. For example, Bowen and Zapata (2009) examined the case study of the Mexican GI tequila produced in the area of Amatitan. The introduction of innovations from industrial productions disrupted the traditional practices entailed in the PS and simultaneously had negative economic, social, and environmental impacts on the area. The authors suggest nourishing traditional practices with innovation to foster a sustainable product (Bowen \& Zapata, 2009). On the contrary, positive effects can be found in the case study of the Sorana bean PGI by Belletti, Marescotti, and Brazzini (2017). Due to the GI label, the small geographical area producers benefitted from a higher selling price and were able to develop social activities, e.g. agritourism, which strengthened the local identification of the product. Lacking economic pressure, the producers could also innovate production steps. All these impacts on the rural area show that the GI label is more than just a basic legal protection tool (Belletti et al., 2017). Furthermore, having strict PS with standards may lead to environmental protection. Belletti, Marescotti, Sanz-Cañada, and Vakoufaris (2015) detected this and further hints concerning tradition and innovation in the PS of the GI Spanish olive oil products. Previously, Sanz-Cañada, Coq-Huelva, Sánchez-Escobar and Hervás-Fernández (2012) reached the same conclusion with non-GI olive oils, highlighting that tradition and innovation activate sustainability in rural areas.

The relationship between tradition and innovation in GIs and their impact on sustainability has been frequently investigated in research. However, to our knowledge, there is no publication that attempted to compare EU case studies per product class and GI scheme based on these key themes. In our selected case studies, we look at specific strategies that GI producers, as entrepreneurs, apply through the synergy of innovation and tradition, and 
if these trigger effects on sustainability. We also, examine the different drivers to engage in innovation and tradition. The next section sets the theoretical framework as a basis to the analysis. It presents a new model paradigm for further research in this direction. After offering a description of the applied qualitative methodologies, including the comparative case study design, the fourth section shows the results regarding the three selected cases: Stromberger Pflaume PDO, Carciofo Spinoso di Sardegna PDO, and Vlaams Brabantse tafeldruif PDO. It is followed by a comparative discussion and a conclusion with implications for policy and future research.

\section{Theoretical Framework}

The theoretical framework for analyzing the following case studies is based on three main concepts: rural and sustainable entrepreneurship, the synergy of tradition and innovation (TISyn) model, and sustainability conceptualized through the Triple Bottom-line (TBL). The combination of these shows the operating fields of a GI producer and supports operationalizing empirical findings.

GI producers can be perceived as rural entrepreneurs who act not only within the agricultural sphere but beyond that. Researchers acknowledge that defining rural entrepreneurship is challenging due to its many facets. According to Hoy (1983), a rural entrepreneur focuses on new business opportunities within rural areas that stimulate new activities. A similar opinion is shared by Wortman Jr (1990), who states that an entrepreneurs' primary function is to add new products or technologies in order to exploit opportunities. Recent theories upgrade the definition of rural entrepreneurs to sustainable entrepreneurs whose activities, in the view of Belz and Binder (2017), can yield economic, social and environmental benefits. To engage in all those fields and still be economically profitable, GI producers must find ways to expand the potential of their product. Multifunctionality is one critical approach followed by farmers to comply with this. Van der Ploeg et al. (2000) claim that services connected to the GI product, such as tourism-based activities or eco-friendly initiatives, are necessary opportunities to add to the agricultural function. They also strengthen rural development (van der Ploeg \& Roep, 2003; Belletti \& Marescotti, 2011). Based on a hybrid form of the rural and sustainable entrepreneur and their fields of action, we define GI entrepreneurs as individuals whose goals are to reinforce their product through a balanced combination of economic, social, and environmental values.

A GI producer is constantly in conflict with upkeeping traditional practices and innovating the product to stay competitive on the market, and therefore, resilient towards external changing stimuli (Quiñones Ruiz et al., 2018). According to the EU regulation 1151/2012, traditional products must have a minimum of 30 years of production and commercialization (European Commission, 2012). The traditional practices which are described in the PS might, however, be outdated due to new regulations or market exigencies (Quiñones Ruiz et al., 2018). We state that tradition and innovation coexist and therefore, support the TISyn model proposed by Gocci and Luetge (2020) which aims to explain this synergy in connection to the three dimensions of sustainability. On the one hand, it is argued that GI producers may actively use this synergy to comply with regulations, and protect local heritage or biodiversity; on the other hand, it is acknowledged that the producers might be triggered to engage in this synergy as a response to, for example, changing regulations, unstable market conditions or climate change (Gocci \& Luetge, 2020). The TISyn model, together with the concept of multifunctionality, helps explain the interrelatedness of activities pursued by a GI entrepreneur to upkeep tradition, being economically competitive and sustainable. Examples for positive and negative effects can be found within the introduction (Bowen \& Zapata, 2009; Belletti et al., 2015).

Sustainability is a key goal of many GI stakeholders within rural areas, although it is a challenging term with many facets. The TBL concept represents the three dimensions (social, economic, environmental) and allows certain flexibility within the approach. The first definition of TBL was provided by Elkington (1998), measuring the performance of not only economic values but enclosing social and environmental aspects (Slaper \& Hall, 2011). In research, many different parameters and approaches to TBL have been used. We argue that TBL suits to measure the performance of a GI entrepreneur. Engaging in touristic activities and eco-friendly initiatives balanced with competitiveness will lead to sustainable production of the GI. There are two main obstacles that GI stakeholders are forced to overcome. First, an understanding of the related dimensions is required to be established. Second, a strong network between different parties with shared objectives is essential. To sum up, TBL requires a balanced approach which can solve potential trade-offs and ambiguities (Cohen, Smith, \& Mitchell, 2008; Dyllick \& Hockerts, 2002; Hahn, Figge, Pinkse, \& Preuss, 2010).

In this article, we combine the three concepts entrepreneurship, the TISyn model, and TBL into a new theoretical framework that we call GISETI (Geographical Indication Sustainable Entrepreneurship Tradition-Innovation), visualized in Figure 1. The model arises from a circular interaction between the three concepts. 


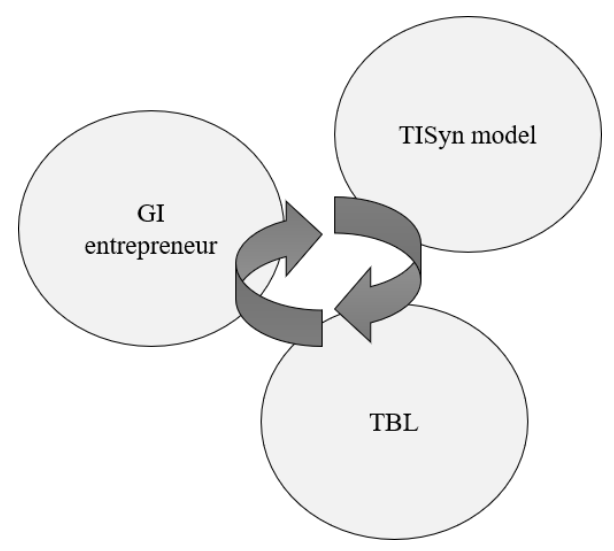

Figure 1. GISETI framework (own elaboration)

The framework is developed to investigate GI case studies while regarding all significant aspects of GI products. The different analyzing steps provide a holistic view and lead to a deeper understanding of GIs. It is also meant to highlight various fields of action where GI producers engage while simultaneously putting them into the context of sustainability and the synergy of innovation and tradition. The latter is vital to upkeep traditional practices within the GI production. The framework will help future researchers investigate GI cases, supporting the European Commission's interests towards the synergy of tradition and innovation. Furthermore, it can help policymakers shape the regulations that foster this synergy and sustainability since there is no written reference within the rules provided by the European Commission.

\section{Methods}

In order to respond to the research questions, we decided to use a comparative case study design with a mixed method approach. It is commonly used in the GI research field, because of its ability to view cases in their context and, therefore, allowing a detailed analysis with reduced positionality of the researcher (Yin, 2009). Before selecting the case studies, a qualitative content analysis of all single documents from the DOOR (Database of Origin and Registration) database was carried out. The database encloses all Single Documents of PDOs and PGIs in different status (application, registration, publicly released) and with all required metadata (e.g. country, registration dates) (European Commission, 2019). The main goal of the qualitative content analysis was to identify products directly or indirectly related to the topics of tradition, innovation, and sustainability. It covered an amount of 1398 registered single documents from which 47 show signs of this relationship. In order to make case studies comparable, shared characteristics are required. Therefore, the case studies were exclusively chosen from one product class (1.6 "fruits and vegetables"), one GI scheme (PDO), and different European countries. The GI scheme has a different history of usage among them, which influences the state of legislation and the institutional attention. 22 out of the 47 products with signs of innovation, tradition, and sustainability belong to the product class 1.6. Those were used to establish preliminary contact requesting cooperation for this study. A successful collaboration was established with the following three products: "Carciofo Spinoso di Sardegna" an artichoke produced in Sardinia, Italy, "Stromberger Pflaume" a plum produced in North Westphalia, Germany and "Vlaams Brabantse tafeldruif" table grapes from Flanders, Belgium.

Semi-structured interviews with producers were carried out between July and November 2019 (see Table 1). Some of them display a double function and are not only producers but presidents or directors of the association or consortium of the GI product. The interviews were prepared with open questions from the three dimensions of sustainability, tradition and innovation and had a duration between 60 and 120 minutes. As preparation for further analysis, they were recorded and transcribed. A software-supported qualitative content analysis (MAXQDA) of the interviews was conducted to identify the central notions and patterns of information (Massengil, 2014). The interviews were coded following the two-step coding methodology of Gioia, Corley and Hamilton (2013) after agreement of the coding criteria to minimize the biases. In the 1st order, the different concepts were identified (e.g. tradition of production, environmental protection, tourism, profit, improvements/adjustments of the product). In the 2nd order analysis the themes were identified (e.g. traditional, innovative, environmental, economic, social), and then aggregated into the main dimensions tradition, innovation and sustainability (Gioia et al., 2013). During the coding, literature of GI research was considered to take into 
account a wider theoretical background.

The main challenge with the interviews was recruiting producers, since all three cases are considered niche products and are organized in small associations. Furthermore, the complexity of the topics was an additional limiting factor. Knowledge gaps were small because the directors or presidents of the associations/consortiums were aware of the other members' situation. To broaden the perspective, targeted surveys were sent to stakeholders such as state agencies, retailers, and agricultural marketing centers. This reduces possible influences from the positionality of the producers. Additionally, the interviews and surveys were backed up with supplementary material (e.g. national product specifications, amendments at EU level when possible, statutes, newsletters, websites, and other hard copies), in order to reach the information saturation required for in-depth case studies. Table 1 gives an overview of all collected and analyzed material.

Table 1. Empirical data sources of case studies

\begin{tabular}{|c|c|c|c|}
\hline & $\begin{array}{c}\text { Germany: Stromberger } \\
\text { Pflaume }\end{array}$ & $\begin{array}{c}\text { Italy: Carciofo Spinoso } \\
\text { di Sardegna }\end{array}$ & $\begin{array}{l}\text { Belgium: Vlaams } \\
\text { Brabantse tafeldruif }\end{array}$ \\
\hline Documents & \multicolumn{3}{|c|}{$\begin{array}{l}\text { Amendment approvals, applications, original and current Product } \\
\text { Specifications (from Door database and organizations of selected countries } \\
\text { (Ministry of Agriculture, Consortia)), case-specific documents (e.g. statutes, } \\
\text { newsletters, websites, brochures, booklets) }\end{array}$} \\
\hline $\begin{array}{l}\text { Interviews, surveys and } \\
\text { affiliations }\end{array}$ & $\begin{array}{l}1 \text { PDO producer \& } \\
\text { president of association } \\
1 \text { retailer } \\
1 \text { officer from LANUV }\end{array}$ & $\begin{array}{l}1 \text { director of } \\
\text { consortium, laboratory } \\
\text { technician \& PDO } \\
\text { producer } \\
1 \text { president of } \\
\text { association \& PDO } \\
\text { producer } \\
1 \text { supervisory \& PDO } \\
\text { producer }\end{array}$ & $\begin{array}{l}1 \text { PDO producer \& vice } \\
\text { president of association } \\
1 \text { PDO producer } \\
1 \text { VLAM, } \\
\text { agri-marketing agency } \\
1 \mathrm{CVBB} \text {, agricultural } \\
\text { agency }\end{array}$ \\
\hline
\end{tabular}

\section{Results}

In the following, the results of the three case studies are presented. First, a general overview of the product is given. Second, the local importance of the product is highlighted, which is followed by explaining the different effects of the GI label. Lastly, the different innovations and their influence on tradition and sustainability will conclude each case study. An overview is provided in Table 2.

Table 2. General context \& organization of the three case studies

\begin{tabular}{|c|c|c|}
\hline Stromberger Pflaume & Carciofo Spinoso di Sardegna & Vlaams Brabantse tafeldruif \\
\hline $\begin{array}{ll}\text { - } & \text { Small geographical area } \\
\text { - } & \text { Small association* } \\
\text { - } & \text { Legal \& financial support for } \\
& \text { registration process } \\
\text { - } & \text { Diverse selling strategies } \\
\text { - } & \text { Stable price with retailer } \\
\text { because of GI }\end{array}$ & $\begin{array}{ll}\text { - } & \text { Small-medium } \\
\text { geographical area } \\
\text { - } & \text { Small association* } \\
\text { - } & \text { Legal support for } \\
& \text { registration process } \\
\text { - } & \text { Diverse selling } \\
\text { strategies } \\
\text { - } & \text { Stable price with the } \\
& \text { GDO because of GI }\end{array}$ & 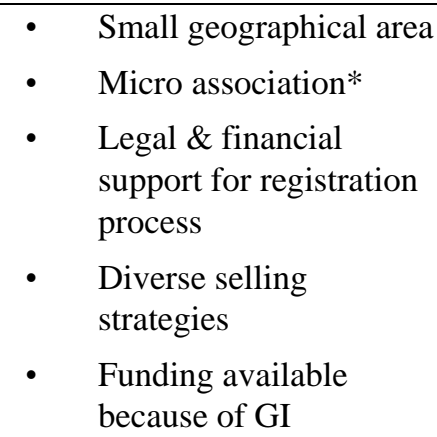 \\
\hline
\end{tabular}




\subsection{Case Study 1: Stromberger Pflaume}

The first case study is about the PDO Stromberger Pflaume, a plum that is cultivated in the district of Stromberg, Northern Germany. The geographical area is rather small; it entails the town Oelde and a 500-meter-wide zone around its borders. In 1790 a merchant named Ludwig Niedieck planted the first imported plum trees from France in the area, thus, it shows around 230 years of traditional production. In January, the cultivation of the plum starts with pruning and continues throughout the year, depending on the natural water supply. The ripe plums are collected from the end of August until mid-September, which is a short timeframe. Nowadays, a yearly average between 50 and 150 tons per producer is harvested, depending on the number of hectares and the amount of rainfall. In 2008, an association formed, which unified around 15 to 20 farmers who are carrying out this practice as a side-job. The plums are sold in their pure fruit form on regional farmers' markets and to a juice manufacturer for the German and Austrian market. The GI label protection was granted from the EU in 2013. The primary legal and also financial support, throughout the registration process, was provided from the Landesamt fuer Natur, Umwelt und Verbraucherschutz Nordrhein-Westfalen (LANUV), as well as from the EU and the state North Rhine-Westfalia (NRW). It was granted the PDO label, which no other product of NRW has.

The plum is part of the local identity of the region, and the trees have been cultivated for many decades within a family context. The trees are handed down to the next generation together with the land; conflicts may arise when the young generation moves into the cities and neglects the tradition. To reinforce the local identity, a thematic plum market was established in 2004, attracting around 15000 people per annum. The visitors not only enjoy the plum specialties (e.g. liqueur, cake) but spend time visiting the area. A collaboration of the local authorities and the producers created a plum hiking path to boost regional tourism. All tourism activities support the visibility of the product, strengthen the local identity, and valorizes the territory, thus enhancing rural development. Even though the stakeholders work collaboratively, they do have different interests. For the producers, the focus is on economic factors; the social aspects are perceived as additional value and environmental protection is viewed as compliance with the regulations.

Apart from the regional market selling strategies, the Stromberger Pflaume association sells a certain amount of plums to the juice retailer "Van Nahmen". The collaboration was established through a networking event by LANUV. After a quality test, the retailer was convinced of the product and wanted a long-term relationship. It allows the collective of producers to benefit from a stable price $(0.45 € / \mathrm{kg})$ in comparison to the weather depending price of 0.20 to $0.30 € / \mathrm{kg}$. Other commitments to e.g. jam processors are not possible due to the restricted geographical area and the peculiar climate terroir. The GI protection is, in this case, both a gate-keeper for stable contracts and a restrictive factor for the production. There is the conviction that the GI label will grant more benefits in the long-run.

There are two main challenges in the production of plums: first, they highly depend on the water availability and, therefore, are influenced by climate change, and second, the short time-window for the collection. During the last decades, the workforce required for collecting the fruits decreased, and there was an effort for innovation moving away from the manual collection process. In several innovation circles, the harvesting machine as it is used today was invented. It shakes the trees, allowing the plums to fall onto a conveyor where the leaves and branches are cleaned off. The plums are then sorted manually and packed into boxes. This innovation led to a decrease in operational costs and even an enhanced quality of the fruit, since the plum skin is irritated by prolonged contact with the hand. This disruption of the traditional production pushed some producers out of the association, even though it still complies with the GI regulation. The association is not perceived as part of the cultural identification but as an institutional organ. The initial purchase of the harvesting machine is connected with a high cost investment. The producers were able to finance it through a financial support program provided by LANUV and successively integrated by the EU and NRW. The producers affirm that despite this innovation, the plum production tradition remained unchanged and is now more resilient to the market changes.

\subsection{Case Study 2: Carciofo Spinoso di Sardegna}

The Italian product "Carciofo Spinoso di Sardegna" is a PDO artichoke with spines cultivated in specific areas of the island Sardinia. The natural features (e.g. the coloring of the plant, taste) of the product are influenced by the provinces' terroir which leads to a variation of artichoke types, still complying with the PS. The specification dates the first cultivation back to Phoenician times, whereas the first written evidence was found in 1780 pointing towards a long tradition. The growing period starts in July when the artichoke buds are planted in the fields. After weekly phytosanitary treatments and watering, the first harvesting is carried out in November. The process is characterized by highly specialized manual steps which require traditional expertise. In 2011, the European acknowledgement as PDO was granted. For the registration process, external consultants were 
provided by local authorities. However, the expenses had to be covered by the producers. Nowadays, the consortium of artichoke producers counts 32 full-time professionals and eleven packaging stations. In general, the associated producers cultivate the plant in an area between 40 and 100 hectares. Farming areas below 40 hectares cannot comply with the market expectations. The harvest is counted not in kilos but in "heads". An area of 60 hectares yields a yearly average of 2500000 heads. Traditionally, the artichoke is commercialized through the GDO (Italian acronym for "large scale distribution") delivering primarily regional fruit and vegetable markets in Italy. The principal amount of artichokes is presently sold in northern Italy (Lombardia, Piemonte, Liguria); a smaller market exists in Tuscany and Emilia-Romagna. Another selling channel is represented by retailers (e.g. Esselunga) who are asking for a more differentiated product approach (e.g. processed varieties) as a reaction to the decline of artichoke consumption.

In the general opinion among Italians, the artichoke is directly connected to the island of Sardinia. This perceived tie is, however, weaker among the local people. There are social activities e.g. festivals or local markets about the artichoke, having a high potential for sharing traditions. The potential is not fully exploited because some stakeholders (e.g. regional authorities) do not recognize the importance of the product for the island. Farmers, who perceive themselves as entrepreneurs, are trying to diversify their business. One goal is to prolong the touristic season through new attractions, such as agri-tourism, hiking and mountain bike paths, and events connected to the artichoke. This is also seen as a possibility to attract young educated adults back to the island to take over the family businesses.

In Sardinia, the PDO product is often cultivated together with the mainstream variety without spines ("varietà romanesca") which is produced in an economy of scale approach. This led to a decrease in the cultivation of the PDO variety "Carciofo Spinoso", also because the consumer prefers the artichoke without spines. The niche market of the PDO is without real competition, even though other regions have tried to farm the spiny artichoke. Despite the decrease in production, the product can be sold at a stable price of $0.35 €$ per head because the GDO guarantees this price for the GI. To raise awareness, there is a need for market expansion of this product to non-traditional regions. The producers are currently developing a network in the following countries: Germany, Switzerland, and the USA. The network is required because the value of the product only acquires visibility through an artichoke-tasting. In the current situation, the farmers are driven by their passion for the product and its possibility regarding environmental protection and social prospects.

Innovation plays a key role in keeping the product economically profitable and, at the same time, eco-friendly. This case study shows many small innovations among the two types of process and organizational innovation without compromising the traditional production techniques. There was even an attempt to improve the product through genetic manipulation of the buds, which was neglected due to the already well adapted genetic features. The organizational innovations were triggered by the short durability of the plant and the necessity to offer a tailored product to the customers. First, new packaging design was introduced, exploiting the concept of vacuum-packed skin layers, originally used for wrapping bread. Second, a processed ready-to-eat variety, without stem and spines, was developed reacting to sales data provided by the retailers. The result was an artichoke salad made of different Sardinian GI products (e.g. cheese and oil).

Process innovations are adjustments to the production procedure. A common one is the mechanization of traditional manual labor to reduce production costs. Many artichoke producers encounter a lack of workforce and, therefore, mechanized some operations like the collection. The introduction of a drip irrigation system lowered the production costs again, through lower water consumption. Moving away from toxic pesticide use, new phytosanitary products were developed and spread weekly on the fields. Based on a 30-year observation of the farmers, this had a direct effect on the local environment, letting plant and animal species recover. Some years ago, it was discovered that the distance between the artichokes was too small and had to be increased. This led to an amendment of the "Carciofo Spinoso di Sardegna" specification, which was granted by the EU in 2015 (European Commission, 2015). The larger distance helps the plant to respire better and leads to higher quality and yield. The distance and field quality is controlled by unique mini-cameras attached to the chipper cleansing plant residuals.

One could argue that innovations disrupt the traditional way of producing the artichoke. However, these innovations were required to stay competitive within the market. The producers are taking financial risks implementing these measures since no funding from Italian authorities is available. Even though the EU offers funding, the application process, and the time period until it is available clashes with the operational needs of the producers. One of the functions of the consortium is to counterbalance this through collective financing. There is a need for more support from local authorities to boost this product again economically and socially. 


\subsection{Case Study 3: Vlaams Brabantse tafeldruif}

The third case study focuses on a Belgian table grape PDO "Vlaams Brabantse tafeldruif". The geographical region, known as "Druivenstreek" (grape region), is located southeast of Brussels and entails the municipalities of Overijse, Hoeilaart, Huldenberg, and parts of Tervuren. In 1865 the first glasshouse was built for cultivating the "exotic" fruit in optimal conditions. Even today, the white and black varieties of grapes are kept in glasshouses, which are heated at a constant temperature from January on. Until the harvesting period from August until October, the GI producers follow a strict procedure that includes removing branches from the grapes to secure an optimal quality. As a reaction to an initiative from the VLAM (Vlaams Centrum voor Agro-en Visserijmarketing) searching for traditional regional products, an association was formed by three professional grape producers. With legal and financial support from VLAM, the commune of Overijse, the Province of Vlaams Brabant, and the EU, the association registered for the GI label, which was granted in 2008. Even though there are some common activities within the association, production and selling are done on an individual basis. Depending on the size and amount of the glasshouses the production average reaches from five to 20 tons per year. Some exclusively sell the product directly to individuals, whereas others follow a more differentiated approach (e.g. retailers). The primary selling market is the region with customers from the whole of Belgium.

Producing grapes requires specific knowledge about the plant and its reaction to the production steps and the terroir. This knowledge is handed down within families who own an active grape business. Sometimes the generational change cannot happen within the family due to lacking interest in the job. In most cases, the business closes or sometimes is passed to a 'newcomer' who has relatives connected to the grape activity. Before the grape crisis in the postwar period, an estimate of 3000 growers was located in the area, and now they are reduced to seven. They are very passionate about the product, and their heritage bond allowed them to overcome critical periods. A collaboration between the association and the local authorities is shaping the touristic attractions within the region. Next to hiking and bicycling grape tours, teaching courses for hobby grape producers, annual festivals, and events within old glasshouses (e.g. weddings) take place, while the town of Overijse operates a museum about the grapes. These activities attract customers from the entire country, thus reinforcing the local identity of the people and, in the meantime, having positive effects on the sales.

Due to the GI label, the producers have access to financial funding from the EU and local authorities to raise awareness of the grapes. This funding is typically used to improve marketing initiatives such as new packaging or promotional material. The main perception of the GI label is the marketing function, however, its effect on the sales is marginal. In fact, the customers choose the product based on a trust relationship with the producer. Other grapes from Italy or Spain are not in competition with the Belgian grapes because of this. The Vlaams Brabantse tafeldruif PDO has a price range of 14 to $25 € / \mathrm{kg}$, which is significantly higher compared to grapes from other European countries. The price arises from the high specialization of the producers and the high production costs (e.g. heating).

Throughout the years, two main process innovations were introduced; first, new methodologies for using pesticides, and second, changes in the heating system. In Belgium, each farmer is required to collaborate with a laboratory institution to measure the soil values and act if they are out of the norm. Within this collaboration, a consultation took place, which led the grape producers to use biopesticides and even natural remedies (e.g. pheromones to capture insects), and therefore, to be eco-friendlier. The main expenses, as well as impact on the environment, are represented by the heating system. Hence, many innovations took place over the years. The traditional heating material used to be coal, now a transition towards wood pellets, can be observed. Those are also adequate for computer-based heating control systems, thus, reducing manual labor in this process step. The production techniques did not change through these innovations but improved the work efficiency while maintaining the product's quality and environmental sustainability.

\section{Discussion}

The GISETI framework is constructed by the circular interaction of the GI entrepreneur, the TBL concept, and the TISyn model, which is used for analyzing possible outcomes of the synergy of tradition and innovation (Gocci \& Luetge, 2020). Each fragment has been applied in research for various purposes. Their interaction sheds light on the cases presented above. Perceiving GI producers as entrepreneurs engaging in tradition and innovation with a possible outcome to sustainability is the starting point for all the analyses described. GISETI supports the interpretation of all the facets regarding the motivations, triggers, and contexts which cause GI producers to engage in their traditional practices, combined with innovation. The framework can be systematically applied to other GI case studies. 
In Table 3 an overview of the compared case studies is provided as base for the following discussion:

Table 3. Comparison of the case studies

\begin{tabular}{|c|c|c|c|}
\hline & Stromberger Pflaume & Carciofo Spinoso di Sardegna & Vlaams Brabantse tafeldruif \\
\hline Tradition & $\begin{array}{ll}\text { - } & \text { Production since } 1790 \\
\text { - } & \text { Family context } \\
\text { - } & \text { Strong local } \\
& \text { identification }\end{array}$ & $\begin{array}{ll} & \text { Production since } 1780 \\
\text { - } & \text { Family context } \\
\text { - } & \text { Strong local identification }\end{array}$ & $\begin{array}{ll}\text { - } & \text { Production since } 1865 \\
\text { - } & \text { Family context } \\
\text { - } & \text { Strong local } \\
& \text { identification }\end{array}$ \\
\hline Innovation & $\begin{array}{l}\text { - Special harvesting } \\
\text { machinery } \\
\rightarrow \quad \begin{array}{l}\text { Positive economic } \\
\text { impact (decrease of } \\
\text { production costs) }\end{array}\end{array}$ & 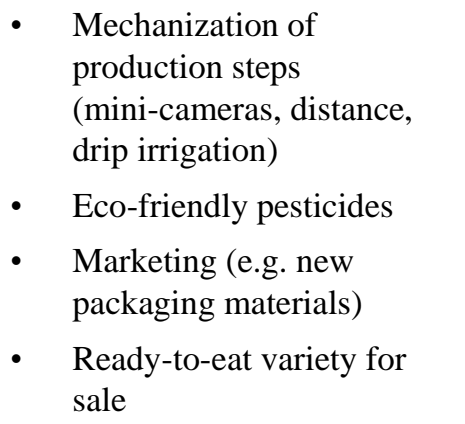 & $\begin{array}{ll}\text { - } & \text { Marketing (e.g. banners) } \\
\text { - } & \text { Heating systems } \\
\text { - } & \text { Eco-friendly pesticides } \\
\rightarrow \quad \begin{array}{l}\text { Positive economic, } \\
\text { environmental impact }\end{array}\end{array}$ \\
\hline & & $\begin{array}{l}\rightarrow \text { Positive economic, } \\
\text { environmental impact }\end{array}$ & \\
\hline Sustainability & $\begin{array}{l}\text { - Thematic plum } \\
\text { market, hiking path } \\
\text { Basic understanding } \\
\text { and engagement in } \\
\text { environmental } \\
\text { activities }\end{array}$ & $\begin{array}{ll}\text { - } & \text { Agri-tourism } \\
\text { - } & \text { Small festivals } \\
\text { - } & \text { Unexploited potential for } \\
\text { social activities } \\
\text { - Overall, results from } \\
\text { economic, social and } \\
\text { environmental perspective. }\end{array}$ & $\begin{array}{ll}\text { - } & \text { Hiking \& Bicycling } \\
\text { grape tours } \\
\text { - } \quad \text { Courses for producing } \\
\text { grapes (hobby) } \\
\text { - } \quad \text { Festivals, museums, } \\
\text { wedding location } \\
\text { - } \quad \text { Cooperation with local } \\
\text { stakeholders concerning } \\
\text { environmental aspects. } \\
\text { Efforts in developing } \\
\text { social activities which } \\
\text { boost tourism. }\end{array}$ \\
\hline
\end{tabular}

The case studies Stromberger Pflaume and Vlaams Brabantse tafeldruif showed that innovation brought economic benefits without harming traditional practices. Simultaneously, through collaboration with local authorities, social and environmental upgrades (e.g. creation of activities related to the product, such as hiking paths and thematic markets) were implemented. The Belgium producers highlighted that linkage with the consumer through social activities yields better financial results. Similar results can be found in the study of Tregear, Török, and Gorton (2016), in which GI producers of Mako PDO benefitted from economic gains through innovation but did not engage adequately in social activities together with local authorities. Following the concept of sustainability, Carciofo Spinoso di Sardegna producers actively pursue the synergy of tradition and innovation. One of the triggers is to keep the artichoke competitive within the market, but also to engage in environmental protection measures. Due to that, innovation is perceived as a main strategy to maintain the products' tradition. The case studies from Belletti et al. (2015) and Belletti et al. (2017) suggest similar conclusions about the role of innovation on sustainability.

All the three products show a strong bond between the local community, its identification with the product, and the geographical area. Despite this, there is a lack of new GI entrepreneurs to take over the production of retiring 
producers since the generational change is not always successful. Newcomers often leave their original business and switch to the production of the GI with support of relatives belonging to the sector, thus, reinforcing the traditional know-how. There is a need for support on sustaining the production of these three GI products, mainly focusing on generational change.

The producers show a range of mild to strong interest in complying with environmental protection measures. Simple and cost-saving environmental strategies are more often pursued since they have a double benefit. The products are economically profitable, even though they represent niche segments of the market and they are produced in small restricted areas. Overall, the GI producers base their production approach on diversification strategies, combining all elements perceived as necessary: passion about the product, economic benefits, social engagement, and environmental protection. This holistic approach, combining tradition and innovation, towards stimulating sustainable practices, should be encouraged within GI policies. The outcome may lead to long-run benefits for all the stakeholders involved.

\section{Conclusion}

In this paper, we show that if innovations are applied in synergy with tradition, positive impacts on sustainability can be observed. GI producers, as entrepreneurs, are able to react to challenges through diversifying their business strategies. The comparative case study highlighted that the national context of legislation is influenced by different funding support programs, the historical usage of GIs and the national interest in them, thus, shaping the GI production strategies. To deliver a comprehensive GI product, tradition and innovation must go hand in hand addressing all three sustainability dimensions.

The case study of Stromberger Pflaume shows a positive effect on economics due to the combination of tradition and innovation. It, however, leaves open questions around the diversification strategies related to social and environmental concerns. Furthermore, Carciofo Spinoso di Sardegna is an example demonstrating the positive effects of using tradition and innovation in synergy. Positive impacts on economic, social, and environmental matters can be observed due to a targeted approach on diversification strategies by the GI artichoke producers. Vlaams Brabantse tafeldruif confirms this statement with particular attention on social aspects in which all stakeholders involve remarkably.

Based on the empirical findings, we support the statement that "GIs are not static museums of production but evolving systems" (Edelmann et al., 2020). This study of the three PDO cases builds new theories around the application of tradition and innovation to the GI scheme and its impact on sustainability. To deliver a broader picture, more studies are required (e.g. analyzing more countries, comparing PGIs, covering larger areas, including quantitative data). We recommend that the implementation of tradition and innovation within the GI scheme receives more support on a worldwide scale. Thus, GI policy officers are required to launch equally accessible programs to everyone. Moreover, future initiatives must focus on the three dimensions of sustainability, which need to be incorporated into the GI regulation. This process should be carried out in collaboration with all GI stakeholders, highlighting the co-existence of social, economic, and environmental benefits.

\section{Acknowledgments}

This research was supported by the Max Planck Institute for Innovation and Competition.

\section{References}

Beckford, C., \& Barker, D. (2007). The role and value of local knowledge in Jamaican agriculture: adaptation and change in small-scale farming. The Geographical Journal, 173(2), 118-128. https://doi.org/10.1111/j.1475-4959.2007.00238.x

Belletti, G., \& Marescotti, A. (2011). Origin products, GI special protection schemes and rural development. In Barham, E., \& Sylvander, B. (Eds.), Labels of Origin for Food. Local Development, Global Recognition (pp. 75-91). Cambridge: CABI International. https://doi.org/10.1079/9781845933524.0075

Belletti, G., Marescotti, A., \& Brazzini, A. (2017). Old World Case Study: The Role of Protected Geographical Indications to Foster Rural Development Dynamics: The Case of Sorana Bean PGI. In W. van Caenegem, \& J. Cleary (Eds.), The Importance of Place: Geographical Indications as a Tool for Local and Regional Development, Ius Gentium: Comparative Perspectives on Law and Justice 58 (pp. 253-276). Springer International Publishing AG. https://doi.org/10.1007/978-3-319-53073-4

Belletti, G., Marescotti, A., Sanz-Cañada, J., \& Vakoufaris, H. (2015). Linking protection of geographical indications to the environment: Evidence from the European Union olive-oil sector. Land Use Policy, 48, 
94-106. https://doi.org/10.1016/j.landusepol.2015.05.003

Belz, F. M., \& Binder, J. K. (2017). Sustainable entrepreneurship: A convergent process model. Business Strategy and the Environment, 26(1), 1-17. https://doi.org/10.1002/bse.1887

Bowen, S., \& Valenzuela Zapata, A. (2009). Geographical indications, terroir, and socioeconomic and ecological sustainability: The case of tequila. Journal of Rural Studies, 25(1), 108-119. https://doi.org/10.1016/j.jrurstud.2008.07.003

Cohen, B., Smith, B., \& Mitchell, R. (2008). Toward a sustainable conceptualization of dependent variables in entrepreneurship research. Business Strategy and the Environment, 17(2), 107-119. https://doi.org/10.1002/bse.505

Dyllick, T., \& Hockerts, K. (2002). Beyond the business case for corporate sustainability. Business Strategy and the Environment, 11(2), 130-141. https://doi.org/10.1002/bse.323

Edelmann, H., Quiñones-Ruiz, X. F., Penker, M., Scaramuzzi, S., Broscha, K., Jeanneaux, P., ... Marescotti, A. (2020). Social Learning in Food Quality Governance-Evidences from Geographical Indications Amendments. International Journal of the Commons, 14(1), 108-122. http://doi.org/10.5334/ijc.968

Elkington, J. (1998). Cannibals with forks: The triple bottom line of $21^{\text {st }}$ century business. Gabriola island: New Society Publishers. https://doi.org/10.1002/tqem.3310080106

European Commission. (2012). Regulation (EU) No 1151/2012 of the European Parliament and of the Council of 21 November 2012 on quality schemes for agricultural products and foodstuffs. Official Journal of the European Union L, 343, 1-29.

European Commission. (2015). Official Journal of the European Union. EC No. IT-PDO-0105-01325, 24-30.

European Commission. (2016). User guide to the SME Definition: European Commission. Brussels: Enterprise and Industry Publications.

European Commission. (2019). DOOR Database. Retrieved December 10, 2019, from http://ec.europa.eu/agriculture/quality/door/list.html?locale=en

Gioia, D. A., Corley, K. G., \& Hamilton, A. L. (2013). Seeking qualitative rigor in inductive research: Notes on the Gioia methodology. Organizational research methods, 16(1), 15-31. https://doi.org/10.1177\%2F1094428112452151

Gocci, A., \& Luetge, C. (2020). The Synergy of Tradition and Innovation Leading to Sustainable Geographical Indication Products: A Literature Review. Journal of Management and Sustainability, 10(1), $152-161$. https://doi.org/10.5539/jms.v10n1p152

Hahn, T., Figge, F., Pinkse, J., \& Preuss, L. (2010). Trade-offs in corporate sustainability: You can't have your cake and eat it. Business Strategy and the Environment, 19(4), 217-229. https://doi.org/10.1002/bse.674

Hobsbawm, E., \& Ranger, T. (2012). The invention of tradition. Cambridge: Cambridge University Press. https://doi.org/10.1080/00103829.1983.12069103

Hoy, F. (1983). A program for rural development from inception through implementation. Journal of the Community Development Society, 14(2), 33-49. https://doi.org/10.1080/00103829.1983.12069103

Lundvall, B. A. (2010). National systems of innovation: Toward a theory of innovation and interactive learning. London and New York: Anthem press. https://doi.org/10.7135/UPO9781843318903

Mancini, M. C. (2013). Localised Agro-Food Systems and Geographical Indications in the Face of Globalisation: The Case of Queso Chontaleño. Sociologia Ruralis, 53(2), 180-200. https://doi.org/10.1080/00103829.1983.12069103

Marescotti, A., Quiñones-Ruiz, X. F., Edelmann, H., Belletti, G., Broscha, K., Altenbuchner, C., ... Scaramuzzi, S. (2020). Are Protected Geographical Indications Evolving Due to Environmentally Related Justifications? An Analysis of Amendments in the Fruit and Vegetable Sector in the European Union. Sustainability, 12(9), 3571-3589. https://doi.org/10.3390/su12093571

Massengil, R. P. (2014). Writing Sociology: A Guide for Senior Theses. Princeton, NJ: Princeton University.

Nuvolari, A., \& Tartari, V. (2014). Innovation, appropriability and productivity growth in agriculture: a broad historical viewpoint. In M. Cimoli, G. Dosi, K. E. Maskus, R. L. Okediji \& J. H. Reichman (Eds.), Intellectual Property Rights: Legal and Economic Challenges for Development (pp. 242-263). Oxford University Press. https://doi.org/10.1093/acprof:oso/9780199660759.003.0008 
Quiñones Ruiz, X. F., Forster, H., Penker, M., Belletti, G., Marescotti, A., Scaramuzzi, S., ... Altenbuchner, C. (2018). How are food Geographical Indications evolving? - An analysis of EU GI amendments. British Food Journal, 120(8), 1876-1887. https://doi.org/10.1108/BFJ-02-2018-0087

Quiñones-Ruiz, X. F., Penker, M., Belletti, G., Marescotti, A., Scaramuzzi, S., Barzini, E., ... Samper-Gartner, L.F. (2016), Insights into the black box of collective efforts for the registration of Geographical Indications. Land Use Policy, 57, 103-116. https://doi.org/10.1016/j.landusepol.2016.05.021

Quiñones-Ruiz, X. F., Penker, M., Vogl, C. R., \& Samper-Gartner, L. F. (2015). Can origin labels re-shape relationships along international supply chains? - The case of Café de Colombia. International Journal of the Commons, 9(1), 416-439. http://doi.org/10.18352/ijc.529

Reyes-Garcia, V., Aceituno-Mata, L., Calvet-Mir, L., Garnatje, T., Gómez-Baggethun, E., Lastra, J. J., ... Pardo-de-Santayana, M. (2014). Resilience of traditional knowledge systems: The case of agricultural knowledge in home gardens of the Iberian Peninsula. Global Environmental Change, 24, 223-231. https://doi.org/10.1016/j.gloenvcha.2013.11.022

Riviezzo, A., Garofano, A., Granata, J., \& Kakavand, S. (2017). Using terroir to exploit local identity and cultural heritage in marketing strategies: An exploratory study among Italian and French wine producers. Place Branding and Public Diplomacy, 13(2), 136-149. https://doi.org/10.1057/s41254-016-0036-4

Sanz-Cañada, J., Coq-Huelva, D., Sánchez-Escobar, F., \& Hervás-Fernández, I. (2012). Environmental and territorial problems of the Spanish olive oil sector and priorities for research and innovation: a Delphi analysis. In F. Arfini, M.C. Mancini, \& M. Donati (Eds.) Local Agri-food Systems in a Global World: Market, Social and Environmental Challenges (pp. 173-193). Newcastle upon Tyne: Cambridge Scholars Publishing. https://doi.org/10.5848/CSP.3696.00008

Slaper, T. F., \& Hall, T. J. (2011). The triple bottom line: What is it and how does it work. Indiana Business Review, 86(1), 4-8.

Tregear, A., Török, A., \& Gorton, M. (2016). Geographical indications and upgrading of small-scale producers in global agro-food chains: A case study of the Makó Onion Protected Designation of Origin. Environment and Planning A, 48(2), 433-451. https://doi.org/10.1177\%2F0308518X15607467

van der Ploeg, J. D., \& Roep, D. (2003). Multifunctionality and rural development: the actual situation in Europe. In G. van Huylenbroeck \& G. Durand (Eds.), Multifunctional agriculture: a new paradigm for European agriculture and rural development (pp. 37-54). Aldershot, UK: Ashgate.

van der Ploeg, J. D., Renting, H., Brunori, G., Knickel, K., Mannion, J., Marsden, T., ... Ventura, F. (2000). Rural Development: From Practices and Policies towards Theory. Sociologia Ruralis, 40(4), 391-408. https://doi.org/10.1111/1467-9523.00156

Weichselbaum, E., Benelam, B., \& Soares Costa, H. (2009). Traditional foods in Europe. Retrieved from http://www.eurofir.org/wp-admin/wp-content/uploads/EuroFIR\%20synthesis\%20reports/Synthesis\%20Rep ort\%206_Traditional\%20Foods\%20in\%20Europe.pdf

Wortman Jr, M. S. (1990). Rural entrepreneurship research: An integration into the entrepreneurship field. Agribusiness, 6(4), 329-344. https://doi.org/10.1002/1520-6297(199007)6:4\%3C329::AID-AGR2720060405\%3E3.0.CO;2-N

Yin, R. K. (2009). Case study research: Design and methods (4th ed.). Thousand Oaks, CA: SAGE.

\section{Copyrights}

Copyright for this article is retained by the author(s), with first publication rights granted to the journal.

This is an open-access article distributed under the terms and conditions of the Creative Commons Attribution license (http://creativecommons.org/licenses/by/4.0/). 